Journal of

Health, Medicine and Nursing

(JHMN)

FACTORS INFLUENCING CONTROL OF BLOOD PRESSURE

LEVELS AMONG HYPERTENSIVE ADULT PATIENTS IN

SELECTED HOSPITALS, KAKAMEGA COUNTY, KENYA

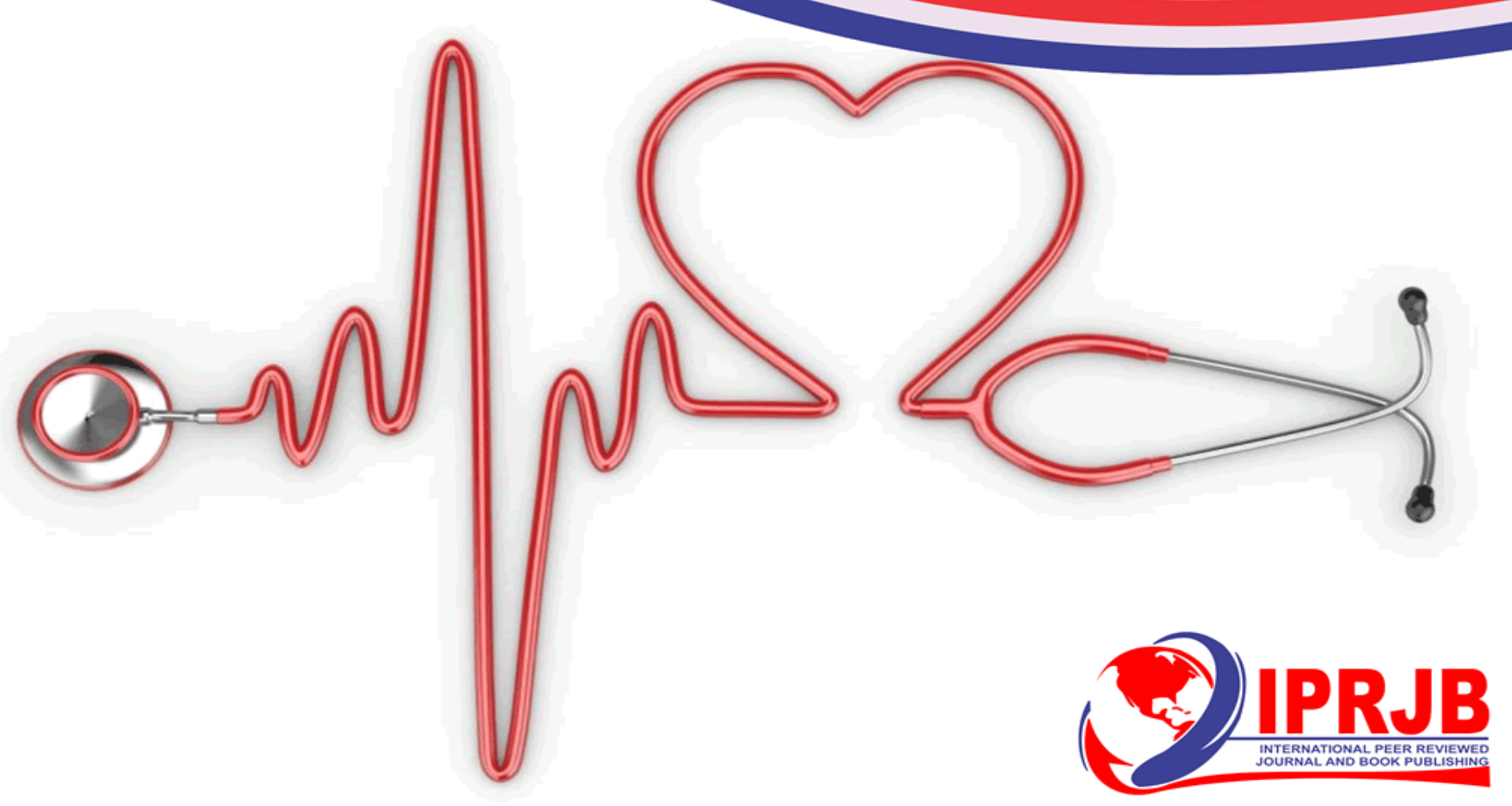




\title{
FACTORS INFLUENCING CONTROL OF BLOOD PRESSURE LEVELS AMONG HYPERTENSIVE ADULT PATIENTS IN SELECTED HOSPITALS, KAKAMEGA COUNTY, KENYA
}

\author{
Thomas Ong'ondo Ng'ambwa ${ }^{1}$ \\ Post Graduate Student: school of Nursing, Midwifery and Paramedical Sciences \\ Masinde Muliro University of Science and Technology \\ Email: tngambwa@mmust.ac.ke \\ Prof. Lt Col (Rtd) John Martin Okoth ${ }^{2}$ \\ Clinical scholar: Department of Nursing Research, Education and Management \\ Masinde Muliro University of Science and Technology \\ Email: jokoth@mmust.ac.ke \\ Dr. Tecla Psusma Sum ${ }^{3}$ \\ Senior lecturer and chair Department of Paramedical Sciences \\ Masinde Muliro University of Science and Technology \\ Email: tsum@mmust.ac.ke
}

\section{Abstract}

Purpose: The study aimed to investigate the factors influencing blood pressure levels in hypertensive adult patients in Kenya's Kakamega County. The specific objectives were as follows: to assess patient factors that influence blood pressure levels among hypertensive adult patients in Kakamega County, examine health-care provider factors that influence blood pressure levels in hypertensive adult patients; determine institutional factors that influence blood pressure levels in hypertensive adult patients in Kakamega County based on the clinical recommendations for cardiovascular disease management from 2018.

Methodology: The researcher used a cross-sectional analytical study design. Patients and health care providers were requested to sign a written consent before data was collected using a questionnaire and an observation checklist. Quantitative data were evaluated using descriptive and inferential statistics, statistical package for social sciences version 22, with a statistically significant $\mathrm{p}$-value of 0.05 . The strength of the relationship between the variables and the patient's blood pressure level was tested using multiple regression.

Findings: The findings showed that the number of years a patient was told he or she had hypertension patient sensitization about the disease $(\mathrm{p}=0.04)$, the patient's BMI $(\mathrm{p}=0.01)$, BP stability at the time of admission (0.0001), having a treatment supporter to advise the patient when to take medications (0.04). The health care provider's age group and knowledge about the disease $(\mathrm{p}=0.02)$ was all separately correlated with blood pressure control. According to the current analysis, in Kakamega County, being a male without adequate patient sensitization about the hypertension disease made patients to be more likely to have uncontrolled blood pressure levels. Unique contribution to theory, practice and policy: The study recommends a model that combines patient and health-care system variables emphasizing on patient sensitization about the 
hypertension disease, modifiable and modifiable risk factors should be created in attempt to have blood pressure controlled.

Key words: Blood pressure control, hypertension, adult patients, kakamega county.

\subsection{INTRODUCTION}

Hypertension is elevated blood pressure above $140 \mathrm{mmHg}$ systolic and $90 \mathrm{mmHg}$ diastolic (Veglio et al., 2013; Kilic et al., 2016). Uncontrolled blood pressure levels result from patients having persistently high blood pressure values beyond the $140 \mathrm{mmHg}$ systolic and $90 \mathrm{mmHg}$ diastolic despite being on medication (MOH, 2016). Uncontrolled blood pressure is the most common cause of death globally, accounting for $31 \%$ of all deaths (WHO,2017). By 2030, the annual number of deaths due to CVD is projected to increase from 17.3 million to 23.6 million. The global prevalence of hypertension is high at $31 \%$ in $2010,28.5 \%$ in high-income countries, and $31.5 \%$ in low-income economies. Recent studies report that in 2015, more than 1.13 billion adults had hypertension, with over $19 \%$ of all deaths related to Uncontrolled blood pressure levels (Dzau \& Balatbat, 2019). Uncontrolled blood pressure has also been associated with not adhering to clinical practice guidelines (Watine et al., 2015). There is clear evidence that Governments' attempts to treat hypertensive patients with uncontrolled blood pressure hypertension have been unsuccessful (Dzau and Balatbat, 2019). Health care providers use the wrong cuff size or do too fast deflation of the cuff when measuring blood pressure(Watine et al., 2015). In Kenya, the prevalence of hypertension has doubled from 6\% in 2009 to $13 \%$ in 2015 (Onyango et al., 2017). Statistics indicate that, out of 10 deaths occurring at different healthcare system levels, hypertension is responsible for six (MOH, 2016). According to Watine, there was overwhelming evidence suggesting that health care providers do not adhere to clinical practice guidelines despite the known benefits of using clinical recommendations; hence, they deliver poor health outcomes to their respective patients (Watine et al., 2015). Uncontrolled blood pressure continues to be a problem for more patients ( Karuri, Wagacha, \& Ochieng, 2014). Furthermore, Kenya's population continues to grow even as research shows that Kenyans are among the least physically fit, predisposing them to hypertension complications (Onywer et al., 2016).

Hypertension affects $15 \%$ of Kakamega County's population of $1,867,579$ people, with most patients with uncontrolled blood pressure receiving referrals, which is higher than the national average (MOH, 2016). Therefore, the current study aimed to investigate factors influencing the blood pressure control among hypertensive adult patients in Kenya: a Kakamega county case study

\subsection{Specific Objectives}

i. To assess patient factors that influence blood pressure levels among hypertensive adult patients in Kakamega County.

ii. To examine the health care provider factors that influence blood pressure levels among hypertensive adult patients in Kakamega county.

iii. To determine institutional factors, influence blood pressure levels among hypertensive adult patients in Kakamega county based on clinical guidelines of 2018. 


\subsection{METHODS AND MATERIALS}

The study used an analytical cross-sectional study design across the six research sites-hospitals in Kakamega County. The study was conducted in selected health facilities offering comprehensive hypertension care services in Kakamega County, selected using the simple random technique. The hospitals included Kakamega, Butere sub-county, Lumakanda, which are public hospitals, while, Mukumu, Nala hospital, and St Mary's Mumias were private. The study population comprised of Hypertensive patients and heath care providers, including doctors, clinicians, and nurses. The sample size was 222 patients and 37 health care providers who were distributed using the sample proportionate distribution. A random sampling technique was used to pick thirty-percent (30\%) of the twenty hospitals (Wayne,2016). Participants were identified using a systematic sampling method. A list of health care providers working in the medical-surgical wards of each hospital was obtained from the duty roster. Based on the sample size required in each hospital per cadre, an interval was calculated by dividing the number of healthcare providers in that cadre by the sample size (population size divided by sample size) in the same cadre at the selected Hospital. The health care provider whose name appeared at the nth number was selected. The questionnaire assessed the sociodemographic variables, lifestyle, presence of support systems like PSSGs. Besides, it had multiple-choice questions to test knowledge on the prognosis of hypertension. The research was pretested on 23 patients and four health care providers at Vihiga County Referral Hospital. The data was gathered over three months. Information on patient factors, health care provider factors, and institutional factors influencing blood pressure control among hypertensive adult patients was collected from the 3rd of February to the 16th of May 2020. Statistical Package for the Social Science program version 22 was used to compile and enter collected data into a computer for review. The statistical methods used were descriptive and inferential. The relationship of independent variables blood pressure levels in adult hypertensive patients in Kakamega county was investigated using multiple regression. Logistic regression analysis was used to analyze the relationship between an independent variable that included patient-specific factors, management factors, and associated health system factors. Statistical significance was identified as a p0.05 value. The study findings were presented in tables and figures.

\subsection{FINDINGS AND DISCUSSIONS}

\subsection{To assess patient factors that influence blood pressure levels among hypertensive adult patients in Kakamega County}

\subsubsection{Patient socio-demographic characteristics}

Table 1 presents socio-demographics of patients interviewed in the various health facilities across Kakamega County, where the study was conducted. More than half $(58.6 \%)$ were females compared to $41.4 \%$ males. The mean age was 64 years and ranges between 38 and 95 years. Most of the respondents were married $(44.6 \%)$, followed by widows $(27.5 \%)$. More than three-quarters $(87.8 \%)$ were Christians. Over one-third $(38.7 \%)$ had attained secondary education while slightly more than a quarter $(26.1 \%)$ had achieved primary level education. Almost half $(49.1 \%)$ were unemployed, with one in five $(21.6 \%)$ employed by either the government or non-governmental organizations (NGOs). In terms of residence and living arrangements, 57.7\% of respondents lived 
in rural areas, while 83.8 percent shared a home with family members. Only $3.6 \%$ live alone. About half $(48.2 \%)$ had three family members living in the house apart from the spouse. Generally, family relations were fair $(63.1 \%)$. Over three-quarters $(78.8 \%)$ had a family member who died of hypertension, with a comparable proportion either being a mother (37.7\%) or sibling (36.6\%). These findings were similar with the study conducted in Ghana which showed respondents were mostly married with ages ranging from 27 to 94 years (Okai et al, 2020). 
Journal of Health, Medicine and Nursing

ISSN 2520-4025 (Online)

Vol.6, Issue 2, No.4, pp 42-71, 2021

www.iprjb.org

Table 1 Patient socio-demographic characteristics

\begin{tabular}{|c|c|c|c|}
\hline Characteristics & Categories & $\mathbf{n}$ & $\%$ \\
\hline \multirow{2}{*}{ Gender } & Male & 92 & 41.4 \\
\hline & Female & 130 & 58.6 \\
\hline \multirow[t]{2}{*}{ Mean age \pm SD (Range) in years } & $\leq 64.0$ & \multirow{2}{*}{\multicolumn{2}{|c|}{$\begin{array}{l}56.0 \pm 5.9(38.0-64.0) \\
73.6 \pm 7.3(65.0-95.0)\end{array}$}} \\
\hline & $>64.0$ & & \\
\hline \multirow{4}{*}{ Marital status } & Single & 23 & 10.4 \\
\hline & Married & 99 & 44.6 \\
\hline & Separated & 39 & 17.6 \\
\hline & Widowed & 61 & 27.5 \\
\hline \multirow[t]{3}{*}{ Religion } & Christian & 195 & 87.8 \\
\hline & Muslim & 18 & 8.1 \\
\hline & Other & 9 & 4.1 \\
\hline \multirow[t]{5}{*}{ Level of education } & None & 35 & 15.8 \\
\hline & Primary & 58 & 26.1 \\
\hline & Secondary & 86 & 38.7 \\
\hline & Diploma & 34 & 15.3 \\
\hline & University & 9 & 4.1 \\
\hline \multirow[t]{4}{*}{ Employment status } & Unemployed & 109 & 49.1 \\
\hline & Self-employed & 65 & 29.3 \\
\hline & Non-government & 24 & 10.8 \\
\hline & Government & 24 & 10.8 \\
\hline \multirow[t]{4}{*}{ Income in KSh. } & Below 11,000 & 115 & 51.8 \\
\hline & $11,000-20,000$ & 36 & 16.2 \\
\hline & $21,000-30,000$ & 40 & 18.0 \\
\hline & $>30,000$ & 31 & 14.0 \\
\hline \multirow[t]{2}{*}{ Place of residence } & Urban & 94 & 42.3 \\
\hline & Rural & 128 & 57.7 \\
\hline \multirow[t]{3}{*}{ Living arrangement } & Live alone & 8 & 3.6 \\
\hline & $\begin{array}{l}\text { Live with a family in the } \\
\text { same house }\end{array}$ & 186 & 83.8 \\
\hline & Live near family & 28 & 12.6 \\
\hline \multirow{3}{*}{$\begin{array}{l}\text { Number of family members living in } \\
\text { the house apart from spouse }\end{array}$} & 1 & 54 & 24.3 \\
\hline & 2 & 61 & 27.5 \\
\hline & 3 & 107 & 48.2 \\
\hline \multirow[t]{3}{*}{ Family relations } & Good & 65 & 29.3 \\
\hline & Not good & 17 & 7.7 \\
\hline & Fair & 140 & 63.1 \\
\hline \multirow{3}{*}{$\begin{array}{l}\text { A family member has died of } \\
\text { hypertension }\end{array}$} & Yes & 175 & 78.8 \\
\hline & No & 10 & 4.5 \\
\hline & Do not know & 37 & 16.7 \\
\hline \multirow{2}{*}{$\begin{array}{l}\text { Relationship with the dead family } \\
\text { member }\end{array}$} & Father & 45 & 25.7 \\
\hline & Mother & 66 & 37.7 \\
\hline
\end{tabular}




\subsubsection{Patient hypertension history}

Table 2 shows respondents' hypertension medical history. The majority (62.6\%) had a history of hypertension lasting more than four years, with $28.8 \%$ having had the chronic illness for between $3-4$ years. Fifty-five percent also presented with diabetes mellitus and $21.6 \%$ with stroke. Less than a third $(31.1 \%$ ) had controlled BMI while $22.1 \%$ fell in the overweight category and $14 \%$ obese. Over half (52.2\%) went for a scheduled medical check-up, mostly monthly (51.7\%).

Respondents were also asked about the type of environment in which they were receiving care. More than two-thirds (71.6\%) perceived the care as somehow hostile, with less than one in ten $(8.6 \%)$ agreeing that the care providers were friendly.

Table 2 Patient hypertension history

\begin{tabular}{|c|c|c|c|}
\hline Characteristics & Categories & $\mathbf{n}$ & $\%$ \\
\hline When the patient was & $<1$ year ago, & 2 & 0.9 \\
\hline told they had & $1-2$ & 17 & 7.7 \\
\hline \multirow[t]{2}{*}{ hypertension in years } & $3-4$ & 64 & 28.8 \\
\hline & $>4$ & 139 & 62.6 \\
\hline \multirow[t]{5}{*}{ Other health complaints } & None & 20 & 9.0 \\
\hline & Rheumatic heart fever & 13 & 5.9 \\
\hline & Stroke & 48 & 21.6 \\
\hline & Diabetes mellitus & 123 & 55.4 \\
\hline & Kidney problem & 18 & 8.1 \\
\hline BMI (Underweight) & $<18.5$ & 73 & 32.9 \\
\hline BMI (Controlled) & $18.5-24.9$ & 69 & 31.1 \\
\hline BMI (Overweight) & $25.0-29.9$ & 49 & 22.1 \\
\hline BMI (Obese) & $>30.0$ & 31 & 14.0 \\
\hline \multirow{3}{*}{$\begin{array}{l}\text { Goes for scheduled } \\
\text { medical checkups }\end{array}$} & Yes & 116 & 52.2 \\
\hline & No & 76 & 34.2 \\
\hline & Do not know & 30 & 13.5 \\
\hline \multirow{4}{*}{$\begin{array}{l}\text { Medical } \\
\text { frequency }\end{array}$} & Weekly & 8 & 6.9 \\
\hline & Fortnightly & 6 & 5.2 \\
\hline & Monthly & 60 & 51.7 \\
\hline & Quarterly & 42 & 36.2 \\
\hline \multirow{4}{*}{$\begin{array}{lll}\text { Perception } & \text { of } & \text { care } \\
\text { provided } & \text { by } & \text { care } \\
\text { providers } & & \end{array}$} & Friendly & 19 & 8.6 \\
\hline & Somehow hostile & 159 & 71.6 \\
\hline & Cannot comment & 41 & 18.5 \\
\hline & Other & 3 & 1.3 \\
\hline
\end{tabular}




\subsubsection{Blood pressure levels and controls}

At the time of admission, $17.6 \%$ of patients had blood pressure between optimal and average, rising to $28 \%$ when the study was performed. Grade 3 (severe hypertension) cases decreased from 29.3 percent at admission to 7.7 percent when data was collected (Figure 1).

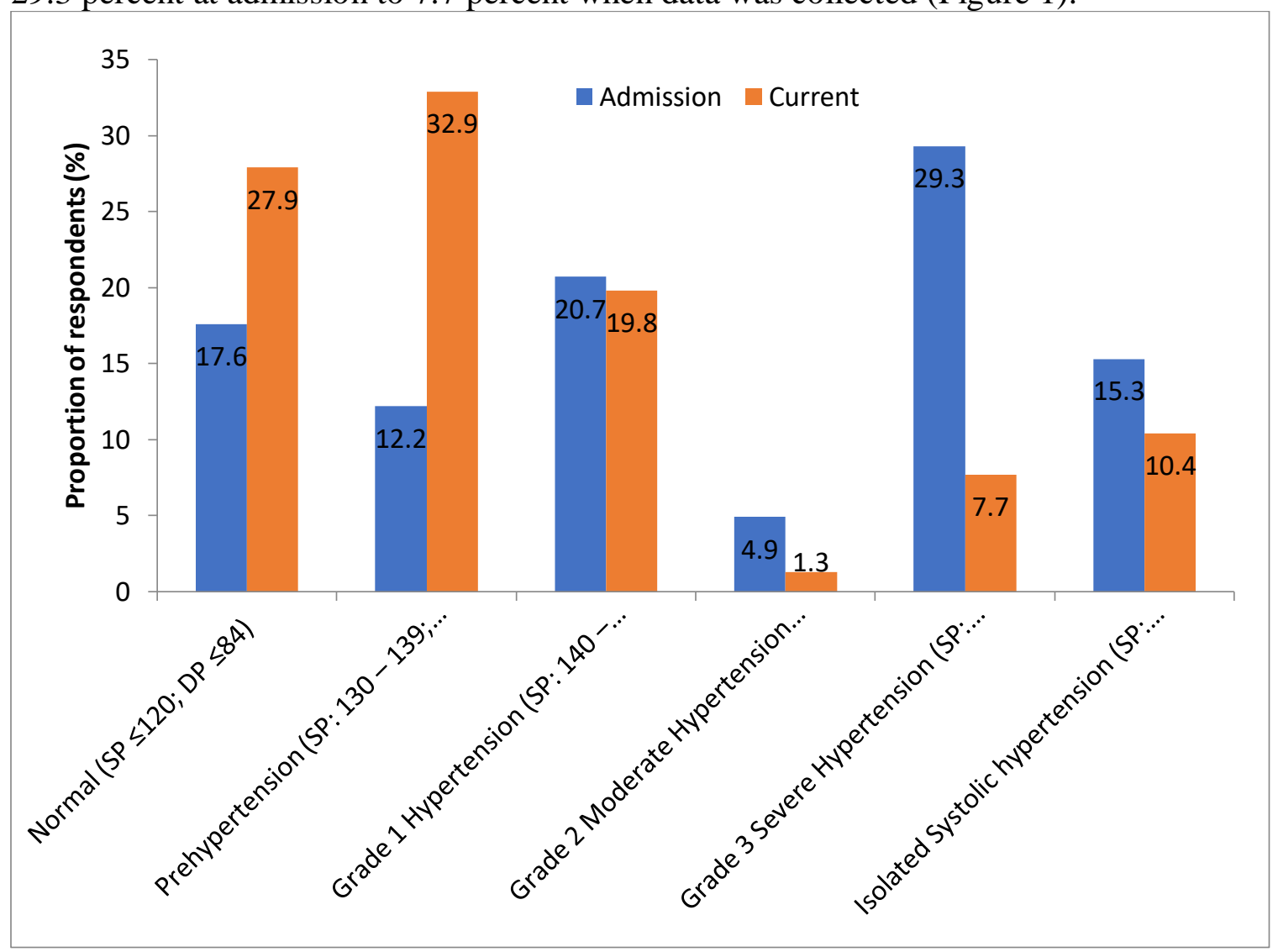

Figure 1 Blood pressure categories during admission and current values

\subsubsection{Lifestyle practices}

The study also examined lifestyle practices among the patients interviewed and the results presented in Table 3 Nearly all (97.3\%) consumed iodized salt. Ninety-eight percent added salt at the table, with $60.8 \%$ adding between $3-4$ teaspoons of salt per day. Again majority (96.4\%) consumed processed food at least every day, with $49.1 \%$ eating whatever was available not paying attention to the composition of the diet. Just 4.5 percent of people did less than 60 minutes of moderate-intensity physical activity during the week. In the previous 12 months, one-fifth (19.8\%) had smoked cigarettes. 
Journal of Health, Medicine and Nursing

ISSN 2520-4025 (Online)

Vol.6, Issue 2, No.4, pp 42-71, 2021

www.iprjb.org

Table 3 Lifestyle modification

\begin{tabular}{|c|c|c|c|}
\hline Characteristics & Categories & $\mathbf{n}$ & $\%$ \\
\hline \multirow[t]{3}{*}{ Consumes iodized salt } & Yes & 216 & 97.3 \\
\hline & No & 1 & 0.4 \\
\hline & Do not know & 5 & 2.3 \\
\hline \multirow[t]{2}{*}{ Adds salt at the table } & Yes & 218 & 98.2 \\
\hline & No & 4 & 1.8 \\
\hline \multirow[t]{4}{*}{ Amount of salt consumed per day } & $<$ one teaspoon & 8 & 3.6 \\
\hline & $1-2$ teaspoons & 59 & 26.6 \\
\hline & $3-4$ teaspoons & 135 & 60.8 \\
\hline & $>4$ teaspoons & 20 & 9.0 \\
\hline \multirow[t]{3}{*}{ Frequency of processed food consumption } & At least every day & 214 & 96.4 \\
\hline & Weekly & 6 & 2.7 \\
\hline & Rarely & 2 & 0.9 \\
\hline \multirow[t]{4}{*}{ Composition of the majority of diet } & Fruits and vegetables & 0 & 0.0 \\
\hline & Fatty food & 1 & 0.4 \\
\hline & Carbohydrates & 112 & 50.5 \\
\hline & What was available & 109 & 49.1 \\
\hline \multirow{6}{*}{$\begin{array}{l}\text { Engages in moderate-intensity physical } \\
\text { activity throughout the week } \\
\text { Frequency of carrying out moderate-intensity } \\
\text { physical activity throughout the week }\end{array}$} & Yes & 10 & 4.5 \\
\hline & No & 212 & 95.5 \\
\hline & $<60$ minutes & 10 & 4.5 \\
\hline & $60-120$ minutes & 0 & 0.0 \\
\hline & $120-180$ minutes & 0 & 0.0 \\
\hline & No at all & 212 & 95.5 \\
\hline \multirow{2}{*}{$\begin{array}{l}\text { Has been smoking cigarettes in the last } 12 \\
\text { months }\end{array}$} & Yes & 44 & 19.8 \\
\hline & No & 178 & 80.2 \\
\hline
\end{tabular}




\subsubsection{Blood pressure check-up and clinical appointments}

Table 4 shows results on blood pressure check-up and clinical appointments. Most of the respondents $(82.4 \%)$ could not remember when last they had their BP checked. Among those who had gone for a check-up, 59.1\% had Grade 1 hypertension. As expected, the majority (97.8\%) had not honored the last three clinical appointments, the main reason being that they forgot (89.9\%). A comparable proportion was currently on Nifedipine (49.1\%) and Hydrochlorothiazide (50.9\%). No health care provider explained to the patients how to take these drugs, with a minority $(9.5 \%)$ having had treatment support to remind them to take medication. Unpredictably, $94.6 \%$ had ever noted adverse effects on the drugs. The most common adverse effects included swelling of limbs (20.9\%), nausea and vomiting (20\%), and cough (19.5\%). Ninety-two percent had ever missed taking medication, the main reasons being the cost of medication (42.6\%) and socio-cultural factors $(40.2 \%)$. 
Table 4 Blood pressure check-up and clinical appointments

\begin{tabular}{|c|c|c|c|}
\hline Characteristics & Categories & $\mathbf{n}$ & $\%$ \\
\hline \multirow[t]{4}{*}{ When last checked, BP } & $<$ Three months ago, & 5 & 2.2 \\
\hline & Three months ago, & 19 & 8.6 \\
\hline & $>$ More than three months & 15 & 6.8 \\
\hline & Cannot remember & 183 & 82.4 \\
\hline \multirow{3}{*}{$\begin{array}{l}\text { Reading of } \mathrm{BP} \text { when } \\
\text { went for check up }\end{array}$} & SP: $120-129$ and DP: $80-84$ & 0 & 0.0 \\
\hline & SP: $130-139$ and DP: $85-89$ & 18 & 40.9 \\
\hline & SP: $140-159$ and DP: $90-99$ & 26 & 59.1 \\
\hline Honored last three & Yes & 5 & 2.2 \\
\hline clinical appointments & No & 217 & 97.8 \\
\hline \multirow{3}{*}{$\begin{array}{l}\text { Reason for missed } \\
\text { appointments }\end{array}$} & Working & 13 & 6.0 \\
\hline & Forgot & 195 & 89.9 \\
\hline & Sick & 9 & 4.1 \\
\hline \multirow{6}{*}{$\begin{array}{l}\text { Current anti- } \\
\text { hypertensive drugs } \\
\text { Explained how to take } \\
\text { the drugs } \\
\text { Has treatment support to } \\
\text { remind the client to take } \\
\text { medication }\end{array}$} & Nifedipine & 109 & 49.1 \\
\hline & Hydrochlorothiazide & 113 & 50.9 \\
\hline & Yes & 0 & 0.0 \\
\hline & No & 222 & 100.0 \\
\hline & Yes & 21 & 9.5 \\
\hline & No & 201 & 90.5 \\
\hline \multirow{9}{*}{$\begin{array}{l}\text { Ever noted adverse } \\
\text { effect on the drugs } \\
\text { Type of adverse effect } \\
\text { experienced }\end{array}$} & Yes & 210 & 94.6 \\
\hline & No & 12 & 5.4 \\
\hline & Swelling of limbs & 44 & 20.9 \\
\hline & Cough & 41 & 19.5 \\
\hline & Constipation & 12 & 5.7 \\
\hline & Erecting problems & 17 & 8.1 \\
\hline & Headache & 38 & 18.1 \\
\hline & Nausea and vomiting & 42 & 20.0 \\
\hline & Feeling nervous & 16 & 7.6 \\
\hline \multirow{6}{*}{$\begin{array}{l}\text { Ever missed taking } \\
\text { medication } \\
\text { Reason for missing } \\
\text { taking medication }\end{array}$} & Yes & 204 & 91.9 \\
\hline & No & 18 & 8.1 \\
\hline & Social/cultural factors & 82 & 40.2 \\
\hline & Religious beliefs & 15 & 7.3 \\
\hline & Cost of medication & 87 & 42.6 \\
\hline & Use of herbal drugs & 20 & 9.8 \\
\hline
\end{tabular}

\subsubsection{Comparison of blood pressure on admission and current readings: Paired t-test}

The paired t-test was used to compare the mean values of patient blood pressure during admission and the study. The null hypothesis was that there was no difference between the two means. SBP and DBP both fell by a statistically significant amount ( $\mathrm{p} \mathrm{0.0001).} \mathrm{This} \mathrm{indicates} \mathrm{that} \mathrm{when} \mathrm{the}$ 
analysis was done, the mean SBP and DBP were substantially lower than the mean SBP and DBP at the entry time.

Table 5 Paired t-test: Comparison of the blood pressure difference between current values and at admission

\begin{tabular}{lllllll}
\hline Blood pressure & $\begin{array}{l}\text { Lower } \\
\text { CL Mean }\end{array}$ & $\begin{array}{l}\text { Upper CL } \\
\text { Mean }\end{array}$ & SD & df & T & P-value \\
\hline $\begin{array}{l}\text { Systolic } \\
\text { difference }\end{array}$ & -15.4 & -10.8 & 17.5 & 221 & - & $<0.0001$ \\
$\begin{array}{l}\text { Diastolic } \\
\text { difference }\end{array}$ & -9.1 & -5.1 & 15.3 & 221 & -6.9 & $<0.0001$ \\
\hline
\end{tabular}

3.2 To examine the health care provider factors that influence blood pressure levels among hypertensive adult patients in Kakamega county.

\subsubsection{Socio-demographic characteristics of health care providers}

A total of 37 health care providers took part in the report. The mean age was 31 years, with a relative mean age of 28.3 for those up to 31 years and 39 years older than 31 years. The participants ranged in age from 23 to 63 years old. The majority of health care providers $(46.9 \%)$ had $1-5$ years of experience, with a minority having served for more than ten years (16.2 percent). More than two-thirds $(68 \%)$ worked in the public health facility, with about half deployed in Level 4 health facilities $(49.6 \%)$.

Table 6 Health care provider characteristics $(n=37)$

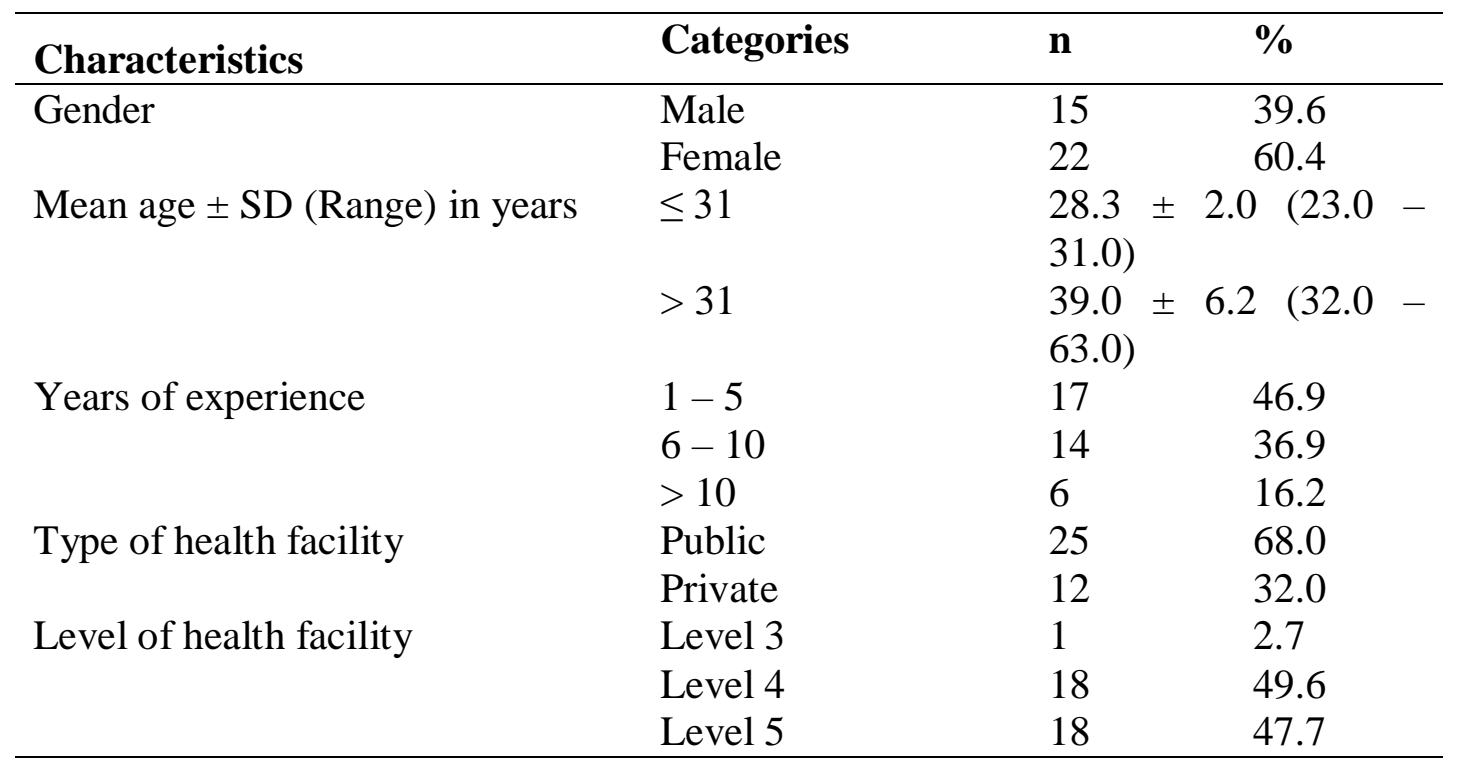




\subsubsection{Health care providers' knowledge on hypertension and blood pressure control}

To assess health care providers' knowledge on hypertension and blood pressure control, several areas were examined. These included knowledge on hypertension assessment, hypertension and uncontrolled blood pressure, hypertensive pharmacology, and various hypertension tests. A total of 27 questions were asked, and the answers were marked. scores were given in percentages, then grades awarded according to the nursing council grading system. ( $75-100 \%$ Distinction, 65$74 \%=$ credit, $50-64$ =pass, 49 and below $=$ Fail). Table 4.7 shows the scores. 4 out of $37(10.8 \%)$ had a Distinction, 6 out of 37 (16.2) had a Credit, 15 out of 37 (40.5\%) had a pass and $12(32.5$ $\%$ ) out of 37 failed which is a considerable percentage

Table 7 Health care providers' knowledge on hypertension and blood pressure control

\begin{tabular}{llll}
\hline Grades & Categories & N & \% \\
\hline Distinction & $75-100 \%$ & 4 & 10.8 \\
Credit & $65-74 \%$ & 6 & 16.2 \\
Pass & $50-64 \%$ & 15 & $\mathbf{4 0 . 5}$ \\
Fail & 49 and below & 12 & 32.5 \\
TOTAL & & $\mathbf{3 7}$ & $\mathbf{1 0 0}$
\end{tabular}

\subsubsection{Availability of clinical guidelines on the management of uncontrolled blood pressure}

The existence of clinical recommendations for treating hypertension in the health facilities represented by the health care professionals interviewed is shown in Table 3.8. The vast majority (97.3\%) of respondents said hypertension was among the top ten conditions in their respective facilities. More than half (54.1\%) have clinical guidelines of 2018 on managing hypertension, with $90 \%$ agreeing that the guidelines are helpful. More than two-thirds $(70.7 \%)$ record the clinical history of the patient. Based on reports from $44.6 \%$ of the respondents, $40 \%$ of patients in the health facilities have controlled BP compared to $50 \%$, as reported by $40.5 \%$ of the respondents. 
Table 8 Availability of clinical guidelines on the management of hypertension and blood pressure control

\begin{tabular}{|c|c|c|c|}
\hline Characteristics & Categories & $\mathrm{n}$ & $\%$ \\
\hline Hypertension among top ten & Yes & 36 & 97.3 \\
\hline conditions in your facility & No & 1 & 2.7 \\
\hline Availability of clinical & Yes & 20 & 54.1 \\
\hline guidelines 2018 on & No & 17 & 45.9 \\
\hline hypertension management & & & \\
\hline if yes, are clinical guidelines & Yes & 18 & 90.0 \\
\hline $\begin{array}{l}2018 \text { on hypertension } \\
\text { management helpful }\end{array}$ & No & 2 & 10.0 \\
\hline \multirow[t]{3}{*}{$\begin{array}{l}\text { why do people feel guidelines } \\
\text { are not helpful }\end{array}$} & $\begin{array}{l}\text { Clinical guidelines (2018) decrease } \\
\text { health care providers' autonomy }\end{array}$ & 9 & 25.0 \\
\hline & $\begin{array}{l}\text { Clinical guidelines (2018) are too } \\
\text { rigid to apply to individual patients }\end{array}$ & 3 & 8.3 \\
\hline & $\begin{array}{l}\text { Clinical guidelines (2018) are } \\
\text { unavailable }\end{array}$ & 25 & 66.7 \\
\hline You record the clinical history & Yes & 26 & 70.7 \\
\hline of the patient & No & 11 & 29.3 \\
\hline From records, the percentage & $40 \%$ & 15 & 40.5 \\
\hline of patients that have controlled & Above $50 \%$ & 17 & 44.6 \\
\hline blood pressure levels & Do not know & 6 & 14.9 \\
\hline
\end{tabular}

\subsubsection{Causes and treatment of hypertension}

As presented in Table 9, 91.9\% of health care providers cited patient beliefs and behaviors as the main cause of uncontrolled BP. Nearly all the respondents agreed that they have defaulters in their facilities, with a minority (13.5\%) providing adherence counseling to patients on the prescribed drugs. To mitigate defaulters, $81.5 \%$ give shorter return dates compared to $18.5 \%$ that send reminder texts. Regarding PSSGS for the client, only $13.5 \%$ affirmed the availability of such services. Asked about the availability of counseling services on a low salt diet to patients, $14.4 \%$ have such services, with another $13.5 \%$ advising patients about lifestyle modification on every visit. Less than one in five (13.5\%) perform investigations on hypertensive patients, with $83.7 \%$ not mentioning any of the most common tests that they perform. The majority $(89.2 \%)$ manage monthly follow-up on their patients. 
Table 9 Causes and treatment of hypertension

\begin{tabular}{|c|c|c|c|}
\hline Characteristics & Categories & $\mathbf{N}$ & $\%$ \\
\hline \multirow[t]{3}{*}{$\begin{array}{l}\text { Causes of uncontrolled blood } \\
\text { pressure }\end{array}$} & $\begin{array}{l}\text { Patient beliefs and } \\
\text { behaviors }\end{array}$ & 35 & 91.9 \\
\hline & Cultural norms & 2 & 5.4 \\
\hline & $\begin{array}{l}\text { Collaborating with the } \\
\text { guidelines }\end{array}$ & 1 & 2.7 \\
\hline \multirow{2}{*}{$\begin{array}{l}\text { Do you have defaulters of } \\
\text { hypertension treatment in your } \\
\text { facility? }\end{array}$} & Yes & 35 & 94.6 \\
\hline & No & 2 & 5.4 \\
\hline \multirow{2}{*}{$\begin{array}{l}\text { Provide adherence counseling to } \\
\text { antihypertensive drugs }\end{array}$} & Yes & 5 & 13.5 \\
\hline & No & 32 & 86.5 \\
\hline \multirow[t]{2}{*}{ How defaulters are managed } & Sending reminder text & 7 & 18.5 \\
\hline & $\begin{array}{lll}\text { Give shorter return } \\
\text { dates }\end{array}$ & 30 & 81.5 \\
\hline \multirow[t]{2}{*}{ Have PSSGS for your client } & Yes & 5 & 13.5 \\
\hline & No & 32 & 86.5 \\
\hline \multirow[t]{2}{*}{ Counsel patients on a low salt diet } & Yes & 5 & 14.4 \\
\hline & No & 32 & 86.5 \\
\hline \multirow{2}{*}{$\begin{array}{l}\text { Advise patients about lifestyle } \\
\text { modification on every visit }\end{array}$} & Yes & 5 & 13.5 \\
\hline & No & 32 & 86.5 \\
\hline \multirow{2}{*}{$\begin{array}{l}\text { Perform investigations on } \\
\text { hypertensive patients }\end{array}$} & Yes & 5 & 13.5 \\
\hline & No & 31 & 83.7 \\
\hline \multirow[t]{3}{*}{ The most common test performed } & $\mathrm{CBC} / \mathrm{FBC}$ & 4 & 10.9 \\
\hline & Urinalysis & 1 & 2.7 \\
\hline & LFTS & 1 & 2.7 \\
\hline \multirow{5}{*}{$\begin{array}{l}\text { How facility manages follow-up } \\
\text { on patients }\end{array}$} & None & 31 & 83.7 \\
\hline & Weekly & 1 & 2.7 \\
\hline & Fortnightly & 1 & 2.7 \\
\hline & Monthly & 33 & 89.2 \\
\hline & Quarterly & 2 & 5.4 \\
\hline
\end{tabular}

\subsubsection{Results of observation checklist for health care provider competence in taking BP}

The competence of health care providers in measuring the BP was assessed by direct observation of preparation and measurement of patients' BP. The direct observation was made easier by using a checklist to track the 37 health care providers as they dealt with the 222 patients who were also interviewed. The checklist with 14 items included equipment preparation and specific procedures of BP measurement. A scoring system was used, with each practice receiving 1 point and each incorrect practice receiving 0 points. A mean score of 6 was determined in this case. Thus, the proportion of health care providers able to competently perform the required procedure was 6 out 
of $14,42.8 \%$ or $43 \%$. The null hypothesis was that the proportion of health care providers competent in performing the procedure was $0.43(\mathrm{p}=0.43)$.

In all 14 items studied, we measured a $\mathrm{z}$-statistic that was greater than the critical value, 1.96 or less, and was correlated with a significance level of $=0.05$. Better performance was reported in gathering equipment and measurement procedures which included: the first sound heard was the systolic pressure, continue to allow air to escape and watch manometer/needle gauge; at the last pulse sound heard, note reading on manometer; release remaining air in the cuff by opening valve completely and remove cuff; and document inpatient record, position, arm used, cuff size, blood pressure measurement to nearest two $\mathrm{mmHg}$, any deviations from measurement protocols, all with highly statistically significant $\mathrm{p}$ values $(\mathrm{p}<0.0001)$.

Negative $\mathrm{z}$ score values with $\mathrm{p}$ values $<0.05$ signify poor performance. As a result, the null hypothesis was rejected for most of the items tested, indicating that the proportion of health care providers who are competent in taking blood pressure is significantly lower than the national average of 0.43 . In 9 out of 14 items, the participating health care providers performed below average, the difference being statistically significant.

Table 10 Observation checklist for health providers competence in taking BP

\begin{tabular}{|c|c|c|c|c|c|}
\hline & No. & $\%$ & $95 \% \mathrm{CI}$ & $\mathbf{Z}$ score & P-value \\
\hline \multicolumn{6}{|l|}{ Equipment } \\
\hline Gather required equipment & 32 & 86.4 & $0.81-0.90$ & 12.8 & $<0.0001$ \\
\hline $\begin{array}{l}\text { Assess correct size cuff and squeeze all } \\
\text { air out before applying to patient } \\
\text { Measurement procedure }\end{array}$ & 11 & 29.7 & $0.24-0.36$ & -3.8 & $<0.0001$ \\
\hline Let patient rest for 5 minutes & 4 & 10.8 & $0.06-0.13$ & -10.1 & $<0.0001$ \\
\hline $\begin{array}{l}\text { Arm preferably right was supported at } \\
\text { the patient's heart level, the palm turned } \\
\text { up }\end{array}$ & 7 & 18.9 & $0.14-0.24$ & -7.2 & $<0.0001$ \\
\hline $\begin{array}{l}\text { Palpate brachial pulse, place cuff on bare } \\
\text { arm }\end{array}$ & 4 & 10.8 & $0.06-0.13$ & -10.1 & $<0.0001$ \\
\hline $\begin{array}{l}\text { Position diaphragm of stethoscope over } \\
\text { brachial pulse site }\end{array}$ & 5 & 13.5 & $0.08-0.16$ & -9.3 & $<0.0001$ \\
\hline Close valve on bulb and inflate cuff & 8 & 21.6 & $0.15-0.26$ & -6.7 & $<0.0001$ \\
\hline $\begin{array}{l}\text { Add } 20-30 \mathrm{mmHg} \text { to } \mathrm{SBP} \text { or } 20-30 \\
\mathrm{mmHg} \text { above the patient's-controlled BP } \\
\text { reading. }\end{array}$ & 10 & 27.0 & $0.22-0.34$ & -4.5 & $<0.0001$ \\
\hline Deflate at 2-3 $\mathrm{mmHg}$ per second & 13 & 35.1 & $0.28-0.40$ & -2.6 & 0.004 \\
\hline $\begin{array}{l}\text { The first sound heard was the systolic } \\
\text { pressure }\end{array}$ & 32 & 86.5 & $0.77-0.87$ & 11.9 & $<0.0001$ \\
\hline $\begin{array}{l}\text { At the last pulse sound heard, note } \\
\text { reading on manometer }\end{array}$ & 31 & 83.8 & $0.77-0.87$ & 11.7 & $<0.0001$ \\
\hline Release remaining air in the cuff & 27 & 73.0 & $0.67-0.78$ & 8.9 & $<0.0001$ \\
\hline
\end{tabular}




\begin{tabular}{llcccc}
\hline $\begin{array}{l}\text { If needs to reinflate to check accuracy, } \\
\text { completely deflate cuff }\end{array}$ & 10 & 27.0 & $0.22-0.34$ & -4.5 & $<0.0001$ \\
\begin{tabular}{l} 
Document inpatient record \\
\hline
\end{tabular} & 27 & 73.0 & $0.66-0.77$ & 8.6 & $<0.0001$ \\
\hline
\end{tabular}

\subsection{To determine health institutional factors, influence blood pressure levels among hypertensive adult patients in Kakamega county based on clinical guidelines of 2018.}

\subsection{1 institutional factors}

Table 11 presents health system factors and patient perception about the system. The majority of the patients $(82 \%)$ confirmed that they were not members of any psychosocial support group (PSSG). A smaller proportion (17.6\%) could access health care providers whenever they needed them, with $72.5 \%$ not being satisfied with the service provided by the health care providers in the clinical appointments. More than a third $(36 \%)$ were satisfied with waiting time while at the waiting bay, and $32 \%$ confirming the ready availability of prescribed drugs in the hospital pharmacy. Asked how long they will use antihypertensive drugs, 31.5\% said 'for life' while 38.7\% would use if BP rises and another $25.2 \%$ whenever sick. A third $(33.8 \%)$ were covered by health insurance. Flyers were issued to $14.9 \%$, with health providers have informed $51.3 \%$ of the importance of blood pressure control and another $33.8 \%$ stating that the cost of services offered was affordable.

Table 11 Institutional factors

\begin{tabular}{llll}
\hline Characteristics & Categories & n & \% \\
\hline $\begin{array}{l}\text { Are you a member of any PSSG in this } \\
\text { facility? }\end{array}$ & Smoking cessation & 25 & 11.3 \\
& Alcohol cessation & 15 & 6.8 \\
Able to access health care providers & No & 182 & 82.0 \\
whenever in need of them & No & 39 & 17.6 \\
Are you satisfied with the service & Yes & 183 & $\mathbf{8 2 . 4}$ \\
provided by health care providers in & No & 61 & 27.5 \\
clinical appointments? & & 161 & $\mathbf{7 2 . 5}$ \\
Are you satisfied with the waiting time & Yes & & \\
while at the waiting bay? & No & 80 & 36.0 \\
Are drugs prescribed readily available in & Yes & 142 & $\mathbf{6 4 . 0}$ \\
hospital pharmacies? & No & 71 & 32.0 \\
For how long will you use & Whenever am sick & 151 & $\mathbf{6 8 . 0}$ \\
antihypertensive drugs? & For life & 70 & 25.2 \\
& When the BP rises & 86 & 31.5 \\
Are you covered by any health insurance & Yes & 10 & 38.7 \\
scheme that caters to treatment bills & No & 75 & 4.50 \\
What education materials does the & Flyers & 147 & 33.8 \\
hospital provide for hypertension & None & 31 & 66.2 \\
& Do not know & 82 & 14.9 \\
\hline
\end{tabular}




\begin{tabular}{lllll}
\hline Have you been informed by health & Yes & 114 & 51.3 \\
providers of the importance of blood & No & 108 & 48.7 \\
pressure control & & & \\
$\begin{array}{l}\text { Was the cost of services offered } \\
\text { affordable }\end{array}$ & No & 75 & 33.8 \\
\hline
\end{tabular}

\subsection{Patient factors that influence control of the blood pressure levels}

Bivariate analysis was used to look at the relationship between the patient's independent variables and the dependent variable, which was calculated as SBP and DBP during the survey period and was either monitored or unregulated (current BP). Controlled BP was considered as SBP $<130$ and $\mathrm{DBP} \leq 84$. Sex and age were two variables that generated statistically significant results. Males had a $50 \%$ lower chance of having regulated blood pressure (OR: $0.5 ; 95$ percent CI: $0.3-1.0 ; \mathrm{p}=$ 0.04). Patients under the age of 64 were $40 \%$ less likely to have controlled blood pressure (OR: 0.6 ; 95 percent CI: $0.3-1.0 ; \mathrm{p}=0.05)$. Those with a family member who had died of hypertension were equally $50 \%$ less likely to have presented with controlled BP, with the p-value of 0.07 being considered as borderline (Table 12).

Though not statistically significant, single, separated, or widows were up to 2.5 times more likely to have had controlled BP. The same finding was found among those with none or primary education and the unemployed who were up to 2.8 and 2.3 times as likely to have had controlled BP compared to their counterparts. 
Journal of Health, Medicine and Nursing

ISSN 2520-4025 (Online)

Vol.6, Issue 2, No.4, pp 42-71, 2021

WWW.iprjb.org

Table 12 Patient factors that influence control of the blood pressure levels

\begin{tabular}{|c|c|c|c|c|c|c|c|}
\hline \multirow[t]{2}{*}{ Characteristics } & \multirow[t]{2}{*}{ Categories } & \multirow[t]{2}{*}{$\mathrm{N}$} & $\begin{array}{l}\text { Blood } \\
\text { status }\end{array}$ & pressure & \multirow[t]{2}{*}{ OR } & \multirow[t]{2}{*}{$95 \% \mathrm{CI}$} & \multirow[t]{2}{*}{ P-value } \\
\hline & & & $\begin{array}{l}\text { Control } \\
\text { led } \\
(\%)\end{array}$ & $\begin{array}{l}\text { Uncontrol } \\
\text { led } \\
(\%)\end{array}$ & & & \\
\hline \multirow[t]{2}{*}{ Gender } & Male & 92 & 20.7 & 79.3 & 0.5 & $0.3-1.0$ & 0.04 \\
\hline & Female & 130 & 33.1 & 66.9 & & & \\
\hline \multirow[t]{2}{*}{ Age } & $<64$ years & 109 & 22.0 & 78.0 & 0.6 & $0.3-1.0$ & 0.05 \\
\hline & $\geq 64$ years & 113 & 27.9 & 66.4 & & & \\
\hline \multirow[t]{2}{*}{ Marital status } & $\begin{array}{l}\text { Single, Separated, } \\
\text { widow }\end{array}$ & 123 & 30.9 & 69.1 & 1.4 & $0.8-2.5$ & 0.3 \\
\hline & Married & 99 & 24.2 & 75.8 & & & \\
\hline \multirow{2}{*}{$\begin{array}{l}\text { Level } \\
\text { education }\end{array}$} & None, Primary & 93 & 33.3 & 66.7 & 1.6 & $0.9-2.8$ & 0.1 \\
\hline & $\begin{array}{l}\text { Secondary, } \\
\text { Tertiary }\end{array}$ & 129 & 24.0 & 76.0 & & & \\
\hline \multirow{2}{*}{$\begin{array}{l}\text { Employment } \\
\text { status }\end{array}$} & Unemployed & 109 & 30.3 & 69.7 & 1.2 & $0.7-2.3$ & 0.4 \\
\hline & Employed & 113 & 25.7 & 74.3 & & & \\
\hline \multirow[t]{2}{*}{ Income in KSh. } & Below 11,000 & 115 & 28.7 & 71.3 & 1.1 & $0.6-1.9$ & 0.8 \\
\hline & $\geq 11,000$ & 107 & 27.1 & 72.9 & & & \\
\hline \multirow[t]{2}{*}{$\begin{array}{l}\text { Living } \\
\text { arrangement }\end{array}$} & $\begin{array}{l}\text { Live with family } \\
\text { in same house }\end{array}$ & 186 & 26.3 & 73.7 & 0.6 & $0.3-1.3$ & 0.2 \\
\hline & $\begin{array}{l}\text { Live alone or Live } \\
\text { near family }\end{array}$ & 36 & 36.1 & 63.9 & & & \\
\hline Number of family & 1 or 2 & 115 & 30.4 & 69.6 & 1.3 & $0.7-2.3$ & 0.4 \\
\hline $\begin{array}{l}\text { members living in } \\
\text { the house apart } \\
\text { from spouse }\end{array}$ & $\geq 3$ & 107 & 25.2 & 74.8 & & & \\
\hline \multirow[t]{2}{*}{ Family relations } & Good & 65 & 21.5 & 78.5 & 0.6 & $0.3-1.2$ & 0.2 \\
\hline & Not good/Fair & 157 & 30.6 & 69.4 & & & \\
\hline A family member & Yes & 175 & 25.1 & 74.9 & 0.5 & $0.3-1.1$ & 0.07 \\
\hline $\begin{array}{ll}\text { has died of } \\
\text { hypertension }\end{array}$ & No/Don't know & 47 & 38.3 & 61.7 & & & \\
\hline Relationship with & Father/Mother & 111 & 26.1 & 73.9 & 1.2 & $0.6-2.4$ & 0.7 \\
\hline $\begin{array}{l}\text { the dead family } \\
\text { member }\end{array}$ & Sibling & 64 & 23.4 & 76.6 & & & \\
\hline
\end{tabular}

\subsection{Patients' medical factors that influence control of the blood pressure levels}

Further analysis was carried out to assess patient medical factors influencing the clinical management of hypertension. Table 13 shows that patients with a lower BMI $(25 \mathrm{~kg} / \mathrm{m} 2)$ had a two-fold higher chance of being monitored than those with an uncontrolled BMI (OR: 1.9; 95 percent CI: $1.0-3.7 ; \mathrm{p}=0.05)$. Patients with managed blood pressure at the time of admission have 
a higher odd of 6 having controlled blood pressure than patients with uncontrolled blood pressure (OR: 6.1; 95 percent CI: 2.9-12.8; p 0.0001). Patients with hypertension diagnosed more than five years earlier and those with diabetes mellitus as a co-morbidity were up to 3.1 and 2.8 times more likely to have regulated blood pressure, respectively, even though the results were non-statistically significant.

Table 13 Patients' medical factors that influence the clinical management of hypertension

\begin{tabular}{|c|c|c|c|c|c|c|c|}
\hline Characteristics & Categories & $\mathrm{n}$ & $\begin{array}{l}\text { Blood } \\
\text { status } \\
\text { Control } \\
\text { led } \\
(\%)\end{array}$ & $\begin{array}{l}\text { Uncontrol } \\
\text { led } \\
(\%)\end{array}$ & OR & $95 \% \mathrm{CI}$ & P-value \\
\hline $\begin{array}{l}\text { When patient was } \\
\text { told had } \\
\text { hypertension in } \\
\text { years }\end{array}$ & $\begin{array}{l}>5 \text { years ago, } \\
\leq 5 \text { years ago, }\end{array}$ & $\begin{array}{l}139 \\
83\end{array}$ & $\begin{array}{l}31.6 \\
21.7\end{array}$ & $\begin{array}{l}68.4 \\
78.3\end{array}$ & 1.8 & $0.9-3.1$ & 0.1 \\
\hline Co-morbidity & $\begin{array}{l}\text { Diabetes mellitus } \\
\text { Others }\end{array}$ & $\begin{array}{l}123 \\
99\end{array}$ & $\begin{array}{l}31.7 \\
23.2\end{array}$ & $\begin{array}{l}68.3 \\
76.8\end{array}$ & 1.5 & $0.8-2.8$ & 0.2 \\
\hline BMI & $\begin{array}{l}<25.0 \\
\geq 25.0\end{array}$ & $\begin{array}{l}142 \\
80\end{array}$ & $\begin{array}{l}32.4 \\
20.0\end{array}$ & $\begin{array}{l}67.6 \\
80.0\end{array}$ & 1.9 & $1.0-3.7$ & 0.05 \\
\hline $\begin{array}{l}\text { Goes for } \\
\text { scheduled } \\
\text { medical checkups }\end{array}$ & $\begin{array}{l}\text { Yes } \\
\text { No }\end{array}$ & $\begin{array}{l}116 \\
106\end{array}$ & $\begin{array}{l}27.6 \\
28.3\end{array}$ & $\begin{array}{l}72.4 \\
71.7\end{array}$ & 1.0 & $0.5-1.7$ & 0.9 \\
\hline $\begin{array}{l}\text { Medical checkup } \\
\text { frequency }\end{array}$ & $\begin{array}{l}1 \text { week }-1 \text { month } \\
>1 \text { month }\end{array}$ & $\begin{array}{l}74 \\
148\end{array}$ & $\begin{array}{l}23.0 \\
30.4\end{array}$ & $\begin{array}{l}77.0 \\
69.6\end{array}$ & 0.7 & $0.4-1.3$ & 0.2 \\
\hline $\begin{array}{l}\text { Perception of care } \\
\text { provided by care } \\
\text { providers }\end{array}$ & $\begin{array}{l}\text { Somehow hostile } \\
\text { Friendly }\end{array}$ & $\begin{array}{l}159 \\
63\end{array}$ & $\begin{array}{l}27.7 \\
28.6\end{array}$ & $\begin{array}{l}72.3 \\
71.4\end{array}$ & 1.0 & $0.5-1.8$ & 0.9 \\
\hline $\mathrm{BP}$ at admission & $\begin{array}{l}\text { Controlled } \\
\text { Uncontrolled }\end{array}$ & $\begin{array}{l}39 \\
183\end{array}$ & $\begin{array}{l}61.5 \\
20.8\end{array}$ & $\begin{array}{l}38.5 \\
79.2\end{array}$ & 6.1 & $\begin{array}{l}2.9 \\
12.8\end{array}$ & $<0.0001$ \\
\hline
\end{tabular}

\subsection{Relationship between patient's lifestyle and control of blood pressure levels}

Table 14 presents results on the relationship between the patient's lifestyle and clinical management of hypertension. None of the results were statistically significant. Interestingly, patients who consumed iodized salt were up to 4.3 times more likely to have controlled BP. Similarly, clients who were consuming processed foods every day engaged in moderate-intensity physical activity throughout the week were up to 23.2 and 4.4, respectively more likely to have controlled BP than their counterparts. 
Table 14 Relationship between patient's lifestyle and clinical management of hypertension

\begin{tabular}{|c|c|c|c|c|c|c|c|}
\hline \multirow[t]{2}{*}{ Characteristics } & \multirow[t]{2}{*}{ Categories } & \multirow[t]{2}{*}{$\mathrm{N}$} & $\begin{array}{l}\text { Blood } \\
\text { status }\end{array}$ & pressure & \multirow[t]{2}{*}{ OR } & \multirow[t]{2}{*}{$95 \% \mathrm{CI}$} & \multirow[t]{2}{*}{ P-value } \\
\hline & & & $\begin{array}{l}\text { Control } \\
\text { led } \\
(\%)\end{array}$ & $\begin{array}{l}\text { Uncontrol } \\
\text { led } \\
(\%)\end{array}$ & & & \\
\hline Consumes & Yes & 216 & 27.8 & 72.2 & 0.8 & $0.1-4.3$ & 0.3 \\
\hline iodized salt & No & 6 & 33.3 & 66.7 & & & \\
\hline Amount of salt & $1-2$ teaspoons & 67 & 25.4 & 74.6 & 0.8 & $0.4-1.6$ & 0.6 \\
\hline consumed per day & $>2$ teaspoons & 155 & 29.0 & 71.0 & & & \\
\hline Frequency of & Everyday & 214 & 28.5 & 71.5 & 2.7 & $0.3-23.2$ & 0.2 \\
\hline $\begin{array}{l}\text { processed food } \\
\text { consumption }\end{array}$ & Weekly/Rarely & 8 & 12.5 & 87.5 & & & \\
\hline Composition of & Carbohydrates & 112 & 30.4 & 69.6 & 1.3 & $0.7-2.3$ & 0.4 \\
\hline $\begin{array}{l}\text { the majority of } \\
\text { diet }\end{array}$ & Others & 110 & 25.4 & 74.6 & & & \\
\hline Engages in & Yes & 10 & 30.0 & 70.0 & 1.1 & $0.3-4.4$ & 0.3 \\
\hline $\begin{array}{l}\text { moderate- } \\
\text { intensity physical } \\
\text { activity } \\
\text { throughout the } \\
\text { week }\end{array}$ & No & 212 & 27.8 & 72.2 & & & \\
\hline Smoked & Yes & 44 & 22.7 & 77.3 & 0.7 & $0.3-1.5$ & 0.4 \\
\hline $\begin{array}{l}\text { cigarettes in last } \\
12 \text { months }\end{array}$ & No & 178 & 29.2 & 70.8 & & & \\
\hline
\end{tabular}

3.7.1 Relationship between patient's clinical check-up appointments and clinical management of uncontrolled blood pressure

Table 15 shows the relationship between patient's clinical check-up appointments and clinical management of hypertension. There was a significant relationship between a patient having treatment support to remind him/her to take medication and clinical management of hypertension. Patients who had such support systems were 2.6 times more likely to have controlled BP than those who did not have the support (OR: 2.6; 95\% CI: $1.0-6.4 ; \mathrm{p} 0.03$ ), with the results being statistically significant. Patients on Nifedipine were $40 \%$ less likely to have controlled BP, unlike patients who stated that they would be on anti-hypertensive treatment for life with a higher likelihood of 1.6 of having controlled BP than those who would be taking treatment whenever they were sick. However, the results for both cases were not statistically significant. 
Journal of Health, Medicine and Nursing

ISSN 2520-4025 (Online)

Vol.6, Issue 2, No.4, pp 42-71, 2021

www.iprjb.org

Table 15 Relationship between patient's clinical check-up appointments and control of blood pressure

\begin{tabular}{|c|c|c|c|c|c|c|c|}
\hline \multirow[t]{2}{*}{ Characteristics } & \multirow[t]{2}{*}{ Categories } & \multirow[t]{2}{*}{$\mathrm{N}$} & $\begin{array}{l}\text { Blood } \\
\text { status }\end{array}$ & pressure & \multirow[t]{2}{*}{ OR } & \multirow[t]{2}{*}{$95 \% \mathrm{CI}$} & \multirow[t]{2}{*}{$\begin{array}{l}\mathrm{P}- \\
\text { value }\end{array}$} \\
\hline & & & $\begin{array}{l}\text { Control } \\
\text { led } \\
(\%)\end{array}$ & $\begin{array}{l}\text { Uncontrol } \\
\text { led } \\
(\%)\end{array}$ & & & \\
\hline When last & Cannot remember & 183 & 29.0 & 71.0 & 1.4 & $0.6-3.1$ & 0.5 \\
\hline checked BP & $\begin{array}{l}\text { Less than one to } \\
\text { more than six } \\
\text { months }\end{array}$ & 39 & 23.1 & 76.9 & & & \\
\hline Honored & Yes & 5 & 20.0 & 80.0 & 0.6 & $0.1-5.8$ & 0.4 \\
\hline $\begin{array}{l}\text { three clinical } \\
\text { appointments }\end{array}$ & No & 217 & 28.1 & 71.9 & & & \\
\hline Reason for & Forgot & 195 & 29.2 & 70.8 & 1.8 & $0.7-5.0$ & 0.2 \\
\hline $\begin{array}{l}\text { missed } \\
\text { appointments }\end{array}$ & Working, sick & 27 & 18.5 & 81.5 & & & \\
\hline Current anti- & Nifedipine & 109 & 22.9 & 77.1 & 0.6 & $0.3-1.1$ & 0.1 \\
\hline $\begin{array}{l}\text { hypertensive } \\
\text { drugs }\end{array}$ & $\begin{array}{l}\text { Hydrochlorothiazi } \\
\text { de }\end{array}$ & 113 & 32.7 & 67.3 & & & \\
\hline Expected & For life & 70 & 34.3 & 65.7 & 1.6 & $0.8-2.9$ & 0.1 \\
\hline $\begin{array}{l}\text { duration of using } \\
\text { anti-hypertensive } \\
\text { drugs }\end{array}$ & $\begin{array}{l}\text { Whenever sick / } \\
\text { when BP rises }\end{array}$ & 152 & 25.0 & 75.0 & & & \\
\hline Has a treatment & Yes & 21 & 47.6 & 52.4 & 2.6 & $1.0-6.4$ & 0.03 \\
\hline $\begin{array}{l}\text { support to remind } \\
\text { client to take } \\
\text { medication }\end{array}$ & No & 201 & 25.9 & 74.1 & & & \\
\hline Ever noted & Yes & 210 & 28.6 & 71.4 & 2.0 & $0.4-9.4$ & 0.2 \\
\hline $\begin{array}{l}\text { adverse effect on } \\
\text { the drugs }\end{array}$ & No & 12 & 16.7 & 83.3 & & & \\
\hline $\begin{array}{l}\text { Type of adverse } \\
\text { effect } \\
\text { experienced }\end{array}$ & $\begin{array}{l}\text { Swelling of limbs, } \\
\text { Constipation, } \\
\text { Headache, } \\
\text { Feeling nervous }\end{array}$ & 110 & 25.5 & 74.6 & 0.7 & $0.4-1.3$ & 0.3 \\
\hline & $\begin{array}{l}\text { Cough, Erectile } \\
\text { problems, nausea, } \\
\text { and vomiting }\end{array}$ & 100 & 32.0 & 68.0 & & & \\
\hline Ever missed & Yes & 204 & 28.9 & 71.1 & 2.0 & $0.6-7.3$ & 0.3 \\
\hline taking medication & No & 18 & 16.7 & 83.3 & & & \\
\hline Reason for & Cost & 87 & 32.2 & 67.8 & 1.3 & $0.7-2.4$ & 0.4 \\
\hline $\begin{array}{l}\text { missing taking } \\
\text { medication }\end{array}$ & Other & 117 & 26.5 & 73.5 & & & \\
\hline
\end{tabular}




\subsubsection{Health care provider factors that influence the clinical management of uncontrolled blood pressure level}

Table 16 shows the factors that affect the clinical treatment of hypertension by health care providers. Patients in Levels 3 and 4 were 50\% less likely than those in Levels 5 and above to have regulated blood pressure (OR; $0.5 ; 95$ percent $\mathrm{CI}: 0.3-0.9 ; \mathrm{p}=0.03$ ). Similarly, patients in private health facilities were $50 \%$ less likely than those in public health facilities to have regulated blood pressure, with the relationship being statistically important (OR: $0.5 ; 95$ percent $\mathrm{CI}: 0.3-1.0 ; \mathrm{p}=$ $0.06)$.

Besides, the proportion of patients aged less than 31 years who had controlled BP was higher $(33.3 \%)$ than those who were older $(22.8 \%)$. Equally, a higher proportion of patients who were counseled on low salt died $(40.6 \%)$ had controlled BP than their colleagues who were not counseled (25.8\%). However, the evidence in both relationships was insufficient to reject the null hypothesis of no relationship between age group, counseling of patients on low salt diet, and clinical management of hypertension assessed through blood pressure changes. Results also indicate that health care providers with clinical guidelines were up to 3 times had more patients (32.5\%) with controlled BP than those without (22.6\%) with a non-significant p-value of 0.1 . The proportion of patients with controlled BP among health care providers who recorded clinical history of patients was higher $(31.2 \%)$ than that of patients with uncontrolled BP whose health care providers were not recording patient history (20\%), results being non-statistically significant. Of importance but with no significant outcomes, Health care professionals that offered adherence therapy (33.3 percent vs. 27.1 percent), had psychosocial support groups (40 percent vs. 26 percent), instructed patients about behavioral modification on any visit (36.4 percent vs. 26.5 percent), and conducted investigations on patients had a higher proportion of patients with managed BP than those with uncontrolled BP (38.5 percent vs. 25.7 percent ). The opposite was true regarding health care provider competence and blood pressure outcome as a measure of good clinical management of hypertension. The proportion of patients with controlled BP among nurses who correctly gathered the correct equipment and those who correctly performed the procedures are much lower, with non-significant results reinforcing the previous results with negative $\mathrm{z}$ score values with $p$ values $<0.05$, signifying poor performance. 
Journal of Health, Medicine and Nursing

ISSN 2520-4025 (Online)

Vol.6, Issue 2, No.4, pp 42-71, 2021

www.iprjb.org

Table 16 Relationship between health care provider factors and control of blood pressure

\begin{tabular}{|c|c|c|c|c|c|c|c|}
\hline \multirow{2}{*}{$\begin{array}{l}\text { Characteristics of } \\
\text { the health care } \\
\text { provider }\end{array}$} & \multirow[t]{2}{*}{ Categories } & \multirow[t]{2}{*}{$\mathrm{n}$} & $\begin{array}{l}\text { Blood } \\
\text { status }\end{array}$ & pressure & \multirow[t]{2}{*}{ OR } & \multirow[t]{2}{*}{$95 \% \mathrm{CI}$} & \multirow[t]{2}{*}{$\begin{array}{l}\mathrm{P}- \\
\text { value }\end{array}$} \\
\hline & & & $\begin{array}{l}\text { Control } \\
\text { led } \\
(\%)\end{array}$ & $\begin{array}{l}\text { Uncontrol } \\
\text { led } \\
(\%)\end{array}$ & & & \\
\hline \multirow[t]{2}{*}{ Gender } & Male & 15 & 23.9 & 76.1 & 0.7 & $0.4-1.3$ & 0.3 \\
\hline & Female & 22 & 30.6 & 69.4 & & & \\
\hline Age group in & $<31$ & 18 & 33.3 & 66.7 & 1.7 & $0.9-3.1$ & 0.08 \\
\hline years & $\geq 31$ & 19 & 22.8 & 77.2 & & & \\
\hline Years & $1-5$ & 17 & 26.0 & 74.0 & 0.8 & $0.5-1.5$ & 0.5 \\
\hline experience & $\geq 6$ & 20 & 29.7 & 70.3 & & & \\
\hline Type of health & Private & 12 & 19.7 & 80.3 & 0.5 & $0.3-1.0$ & 0.06 \\
\hline facility & Public & 25 & 31.8 & 68.2 & & & \\
\hline Level of health & 3 or 4 & 19 & 21.6 & 78.4 & 0.5 & $0.3-0.9$ & $\mathbf{0 . 0 3}$ \\
\hline facility & Five and above & 18 & 34.9 & 65.1 & & & \\
\hline Have clinical & Yes & 21 & 32.5 & 67.5 & 1.6 & $0.9-3.0$ & 0.1 \\
\hline guidelines & No & 16 & 22.6 & 77.4 & & & \\
\hline Records the & Yes & 26 & 31.2 & 68.8 & 1.8 & $0.9-3.6$ & 0.09 \\
\hline $\begin{array}{l}\text { clinical history of } \\
\text { patients }\end{array}$ & No & 11 & 20.0 & 80.0 & & & \\
\hline Percentage of & Above $50 \%$ & 16 & 32.3 & 67.7 & 1.5 & $0.8-2.7$ & 0.2 \\
\hline patients with & $40 \%$ or Don't & 21 & 24.4 & 75.6 & & & \\
\hline controlled BP & know & & & & & & \\
\hline Provide & Yes & 5 & 33.3 & 66.7 & 1.3 & $0.6-3.1$ & 0.5 \\
\hline $\begin{array}{l}\text { adherence } \\
\text { counseling }\end{array}$ & No & 32 & 27.1 & 72.9 & & & \\
\hline Have PSSGS for & Yes & 5 & 40.0 & 60.0 & 1.9 & $0.8-4.2$ & 0.1 \\
\hline patients & No & 32 & 26.0 & 74.0 & & & \\
\hline Counsel patients & Yes & 5 & 40.6 & 59.4 & 2.0 & $0.9-4.3$ & 0.08 \\
\hline on a low salt diet & No & 32 & 25.8 & 74.2 & & & \\
\hline Advise patients & Yes & 6 & 36.4 & 63.6 & 1.6 & $0.7-3.5$ & 0.2 \\
\hline about lifestyle & No & 31 & 26.5 & 73.5 & & & \\
\hline $\begin{array}{l}\text { modification on } \\
\text { every visit }\end{array}$ & & & & & & & \\
\hline Performs & Yes & 7 & 38.5 & 61.5 & 1.8 & $0.9-3.7$ & 0.1 \\
\hline $\begin{array}{l}\text { investigations on } \\
\text { patients }\end{array}$ & No & 32 & 25.7 & 74.3 & & & \\
\hline Gathers the right & Yes & 35 & 27.4 & 72.6 & 0.5 & $0.1-2.3$ & 0.4 \\
\hline $\begin{array}{l}\text { equipment and } \\
\text { assess for correct } \\
\text { size }\end{array}$ & No & 2 & 42.9 & 57.1 & & & \\
\hline
\end{tabular}


Journal of Health, Medicine and Nursing

ISSN 2520-4025 (Online)

Vol.6, Issue 2, No.4, pp 42-71, 2021

www.iprjb.org

\begin{tabular}{lllllllll}
\hline $\begin{array}{l}\text { Correctly } \\
\text { performed } \\
\text { procedures }\end{array}$ & the & No & 36 & 27.2 & 72.8 & 0.2 & 0.04 & -0.1 \\
\hline
\end{tabular}

\subsubsection{Institutional factors influencing clinical management of uncontrolled blood pressure}

Table 17 shows bivariate analysis results on health system factors influencing clinical management of hypertension. None of the results were statistically significant. Despite that, there were important findings that may need further consideration. The proportion of patients with controlled BP was higher where access to health care providers whenever patients were in need (30.8\%), among patients who expressed satisfaction with services provided by health care providers whenever patient had clinical appointment $(34.4 \%)$ or institutions with readily available prescribed drugs in hospital pharmacy $(32.4 \%)$.

Though statistically insignificant, almost three-quarters of the patients felt that the medication cost was too high, with $70 \%$ having uncontrolled blood pressure readings for lack of the necessary drugs. 
Journal of Health, Medicine and Nursing

ISSN 2520-4025 (Online)

Vol.6, Issue 2, No.4, pp 42-71, 2021

$\underline{\text { www.iprjb.org }}$

Table 17 Relationship between health facility factors and control of blood pressure

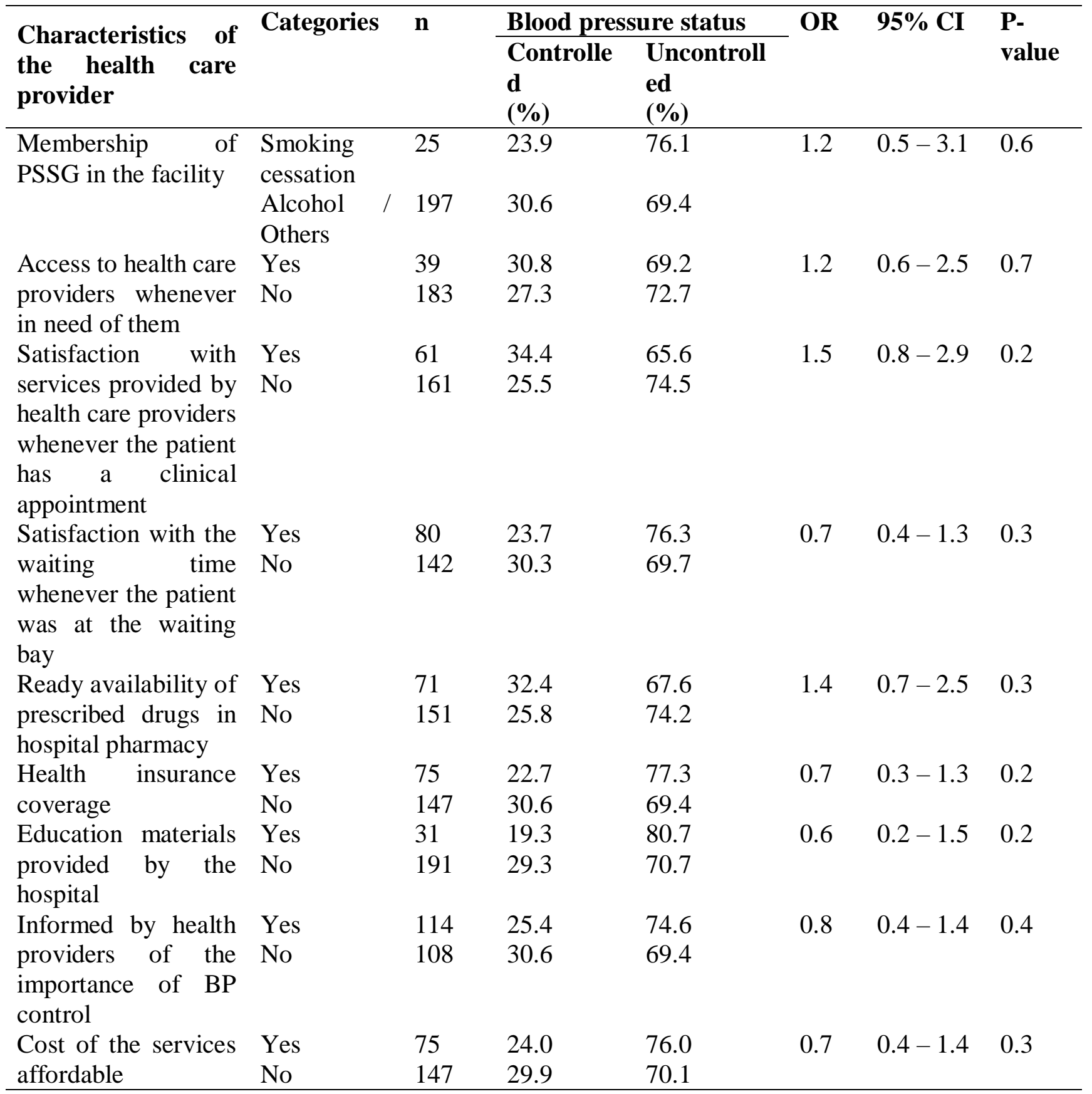




\subsection{Multiple logistic regression on factors associated with the blood pressure levels for the patients}

Multiple logistic regression was performed with all the independent variables with $p \leq 0.1$ as explanatory variables and binary outcome - controlled or uncontrolled BP as a measure of clinical management of hypertension. The model used was to determine which explanatory variable influences clinical management of hypertension and could then be used to predict the outcome. These results indicate that the number of years a patient was told that he/she has hypertension ( $\mathrm{p}$ $=0.04)$, patient's BMI $(\mathrm{p}=0.01)$, control of BP at the time of admission $(<0.0001)$, having treatment supporter to remind patient when to take drugs (0.04) and age group of health care provider $(\mathrm{p}=0.02)$ are independently linked to the clinical treatment of hypertension and blood pressure control in patients. More than five years earlier, patients diagnosed with hypertension were 2.3 times more likely to have their blood pressure under control. Those with controlled BP were 2.9-fold more likely to have had controlled BP at the time of admission. Patients admitted with controlled BP were 5.6 times more likely to have controlled BP while those with treatment supporter or being cared for by a younger health care provider were 3.2 and 2.5 times, respectively more likely to have had controlled BP. Male patients $(p=0.06)$, patients younger than 64 years $(\mathrm{p}=0.07)$, and a family member who died from hypertension were all negative predictors of marginal $\mathrm{p}$ values ( $\mathrm{p}$ 0.06). 
Table 18 Multiple logistic regression on factors associated with control of blood pressure

\begin{tabular}{|c|c|c|c|c|c|}
\hline $\begin{array}{l}\text { Independent } \\
\text { variable }\end{array}$ & Categories & Estimate & OR & $95 \% \mathrm{CI}$ & P-value \\
\hline \multicolumn{6}{|l|}{ Patient factors } \\
\hline Gender & Male vs Female & -0.7 & 0.5 & $0.2-1.0$ & 0.06 \\
\hline Age group in years & $<64 \mathrm{vs} \geq 64$ & -0.7 & 0.5 & $0.2-1.1$ & 0.07 \\
\hline Level of education & $\begin{array}{l}\text { None/Primary vs } \\
\text { Secondary and above }\end{array}$ & -0.1 & 0.9 & $0.4-2.0$ & 0.8 \\
\hline $\begin{array}{l}\text { A family member } \\
\text { died due to } \\
\text { hypertension }\end{array}$ & Yes, vs No & -0.8 & 0.4 & $0.2-1.0$ & 0.06 \\
\hline $\begin{array}{l}\text { When patient was } \\
\text { told that he/she had } \\
\text { hypertension }\end{array}$ & $\begin{array}{l}>5 \text { years vs } \leq 5 \text { years } \\
\text { ago }\end{array}$ & 0.8 & 2.3 & $1.0-5.2$ & 0.04 \\
\hline BMI & $<25.0 \mathrm{vs} \geq 25.0$ & 1.1 & 2.9 & $1.2-6.7$ & 0.01 \\
\hline $\begin{array}{l}\text { Controlled BP during } \\
\text { admission }\end{array}$ & Yes, vs No & 1.7 & 5.6 & $2.2-13.3$ & $<0.0001$ \\
\hline $\begin{array}{l}\text { Type of anti- } \\
\text { hypertensive used }\end{array}$ & $\begin{array}{l}\text { Nifedipine vs } \\
\text { Hydrochlorothiazide }\end{array}$ & -0.5 & 0.6 & $0.3-1.2$ & 0.1 \\
\hline $\begin{array}{l}\text { Has treatment } \\
\text { supporter to remind } \\
\text { patient to take } \\
\text { medication } \\
\text { Health care provider }\end{array}$ & Yes, vs. No & 1.2 & 3.2 & $1.0-10.0$ & 0.04 \\
\hline Age group in years & $<31 \mathrm{vs} \geq 31$ & 0.9 & 2.5 & $1.2-5.3$ & 0.02 \\
\hline $\begin{array}{l}\text { Type of health } \\
\text { facility }\end{array}$ & Private vs Public & -0.4 & 0.7 & $0.2-2.0$ & 0.5 \\
\hline $\begin{array}{l}\text { Availability of } \\
\text { clinical guidelines }\end{array}$ & Yes, vs No & 0.2 & 1.2 & $0.5-2.8$ & 0.7 \\
\hline $\begin{array}{l}\text { Records the clinical } \\
\text { history of the patient }\end{array}$ & Yes, vs. No & 0.3 & 1.3 & $0.5-3.9$ & 0.6 \\
\hline $\begin{array}{l}\text { Have PSSG for } \\
\text { patients }\end{array}$ & Yes, vs No & -0.7 & 0.5 & $0.1-2.7$ & 0.4 \\
\hline $\begin{array}{l}\text { Counsel patients } \\
\text { about low salt diet }\end{array}$ & Yes, vs No & 1.0 & 2.7 & $0.5-15.6$ & 0.3 \\
\hline $\begin{array}{l}\text { Performs } \\
\text { investigations on } \\
\text { hypertensive patients }\end{array}$ & Yes, vs No & 0.7 & 2.0 & $0.3-12.8$ & 0.5 \\
\hline
\end{tabular}

\subsection{Conclusions and Recommendations}




\subsection{Conclusion}

The study results showed that the patient's age and gender directly impact the clinical treatment of hypertension (status of the blood pressure of the patient-controlled or uncontrolled). An overwhelming majority of health care providers confirmed hypertension being among the top ten conditions in the respective facilities. However, more than half $(54.1 \%)$ have clinical guidelines of 2018 on hypertension management, with $90 \%$ agreeing that the guidelines are helpful, with only More than two-thirds $(70.7 \%)$ record the patient's clinical history. More than $30 \%$ did not have adequate knowledge of hypertension and blood pressure control

The patients with controlled BP are higher where access to health care providers whenever patients were in need $(30.8 \%)$, among patients who expressed satisfaction with services provided by health care providers whenever patient had clinical appointment $(34.4 \%)$ or institutions with readily available prescribed drugs in hospital pharmacy (32.4\%). More so, the patients who understood the prognosis of the disease had controlled BP.

\subsection{Recommendations}

In an attempt to improve a patient's Physical activity, nonmodifiable variables like gender and age should be considered as they were statically significant in the current study. Health care providers should get frequent, continuous education on patient-friendly services for better management of hypertension and blood pressure levels

The ministry of health should Provide hypertension clinical management recommendations to health care professionals and use them when delivering comprehensive treatment to hypertensive patients.

Refresher training opportunities for health care professionals delivering comprehensive services to hypertensive patients on blood pressure monitoring and other evaluation skills

Health facilities should conduct frequent health talks on the prognosis of hypertension disease within and outside the hospital for hypertensive patients to improve patient awareness. Health facilities should ensure proper planning and procurement of hypertensive medications to minimize stockouts and control artificial shortages of drugs

According to the current report, males in Kakamega County had higher rates of uncontrolled blood pressure than females. As a result, there was a need for further studies with a large sample size for both patients and healthcare providers.

\section{BIBLIOGRAPHY}

Adamu, U. G., Ibok, I. O., Abdullahi, A., \& Ogundele, I. O. (2014). Knowledge, Attitude and Practice of Physicians in the Treatment of Hypertension in North-Central Nigeria. May, 251-256.

Ameh, S., Gómez-olivé, F. X., Kahn, K., Tollman, S. M., \& Klipstein-grobusch, K. (2017). Relationships between structure, process and outcome to assess quality of integrated chronic disease management in a rural South African setting : applying a structural equation model. 1-15.

Carlsson, A. C., Wändell, P. E., Journath, G., de Faire, U., \& Hellénius, M. L. (2009). Factors associated with uncontrolled hypertension and cardiovascular risk in hypertensive 60-yearold men and women-a population-based study. Hypertension Research, 32(9), 780-785. 
Journal of Health, Medicine and Nursing

ISSN 2520-4025 (Online)

Vol.6, Issue 2, No.4, pp 42-71, 2021

www.iprjb.org

Diseases, D. O. F. N., \& Health, M. O. F. (n.d.). Ministry of health kenya national guidelines for cardiovascular diseases management division of non-communicable diseases republic of kenya kenya national guidelines for cardiovascular diseases management division of noncommunicable diseases.

Dorans, K. S., Mills, K. T., Liu, Y., \& He, J. (2018). Trends in Prevalence and Control of Hypertension According to the 2017 American College of Cardiology/American Heart Association (ACC/AHA) Guideline. 1-11.

Dzau, V. J., \& Balatbat, C. A. (2019). The Need for Transformation. 450-457. https://doi.org/10.1161/HYPERTENSIONAHA.119.13437

Foex, P., \& Sear, J. W. (2004). Hypertension : pathophysiology and treatment. December 2015.

Green, A. S., Lynch, H. M., Nanyonga, R. C., Squires, A. P., Gadikota-Klumpers, D. D., Schwartz, J. I., \& Heller, D. J. (2020). Assessing providers' approach to hypertension management at a large, private hospital in Kampala, Uganda. Annals of Global Health, $86(1), 1-8$.

Kak, N., Burkhalter, B., \& Cooper, M. (n.d.). Measuring the Competence of Healthcare Providers. 1-28.

Karuri, J., Wagacha, P. W., \& Ochieng, D. O. (2014). DHIS2 : The Tool to Improve Health Data Demand and Use in Kenya DHIS2: The Tool to Improve Health Data Demand and Use in Kenya. January.

Keenan, N., Labarthe, D., \& Hong, Y. (2013). NIH Public Access. 1-19.

Kengne, A. P., Sobngwi, E., Fezeu, L., Awah, P. K., Dongmo, S., Mbanya, C., \& Investigators, T. C. (2009). Research article at primary health care level in resource-limited settings of Africa. 8688, 1-10.

Kilic, M., Uzunçakmak, T., \& Ede, H. (2016). The effect of knowledge about hypertension on the control of high blood pressure. International Journal of the Cardiovascular Academy, 2(1), 27-32.

Leonetti, G., Vaccarella, A., Michev, I., Garavelli, G., Cuspidi, C., Magrini, F., Zanchetti, A., Palumbo, G., Lonati, L., Meani, S., \& Cristofari, M. (2002). Compliance to hypertension guidelines in clinical practice: a multicentre pilot study in Italy. Journal of Human Hypertension, 16(10), 699-703.

Lulebo, A. M., Mapatano, M. A., Kayembe, P. K., Mafuta, E. M., Mutombo, P. B., \& Coppieters, Y. (2015). Assessment of hypertension management in primary health care settings in Kinshasa, Democratic Republic of Congo. BMC Health Services Research.

Maharjan, B. (2018). Prevalence and Awareness of Hypertension among Adults and its Related Risk Factors. Journal of Nepal Health Research Council, 15(3), 242-246.

Ministry of Health in Kenya. (2015). Kenya Health Workforce Report : The Status of Healthcare Professionals in Kenya, 2015. 104.

$\mathrm{MoH}$. (2016). Statistical review of progress towards the mid-term targets of the Kenya health sector strategic plan 2014-2018. 199.

Okai, D. E., Manu, A., Amoah, E. M., Laar, A., Akamah, J., \& Torpey, K. (2020). Patient-level factors influencing hypertension control in adults in Accra, Ghana. BMC Cardiovascular Disorders, 20(1), 1-7.

Olin, B. R., Twiggs, J., \& Bell, K. (2015). Hypertension: The silent killer: Updated JNC-8 guideline recommendations. Alabama Pharmacy Association. 
Onyango, M. J., Kombe, I., Nyamongo, D. S., \& Mwangi, M. (2017). A study to determine the prevalence and factors associated with hypertension among employees working at a call centre Nairobi Kenya. Pan African Medical Journal, 27, 1-9.

Panwar, M., \& Tanwar, N. (2018). Chapter - 3. June, 32-50.

Paudel, S. S. (2020). A meta-analysis of 2019 novel corona virus patient clinical characteristics and comorbidities. 1-16.

Price, A. J., Crampin, A. C., Amberbir, A., Kayuni-chihana, N., Musicha, C., Tafatatha, T., Branson, K., Lawlor, D. A., Mwaiyeghele, E., Nkhwazi, L., Smeeth, L., Pearce, N., Munthali, E., \& Mwagomba, B. M. (2018). Prevalence of obesity, hypertension , and diabetes, and cascade of care in sub-Saharan Africa : a cross-sectional, population-based study in rural and urban Malawi. THE LANCET Diabetes \& Endocrinology, 6(3), 208-222.

R., G., \& S., G. (2010). Strategies for initial management of hypertension. Indian Journal of Medical Research, 132(11), 531-542.

Statistics, B. O. F. (2015). KENYA STEP wise SURVEY FOR NON COMMUNICABLE DISEASES RISK FACTORS 2015 REPORT.

Szabo, A. (2020). Differences in life-satisfaction, optimism and pessimism between hypertensive and non-hypertensive adults differences in life-satisfaction, optimism and pessimism between hypertensive and non-hypertensive adults. May.

Thinyane, K. H., Mothebe, T., Sooro, M., Namole, L. D., \& Cooper, V. (2015). An observational study of hypertension treatment and patient outcomes in a primary care setting. In Pan African Medical Journal (Vol. 20).

Veglio, F., Grassi, G., Mancia, G., \& Volpe, M. (2013). Clinical Management of Resistant Hypertension. November.

Vouga, M., Musso, D., Goorhuis, A., Freedman, D. O., Rodgers, A., \& Jaffe, M. G. (2018). Fixed-dose combinations for hypertension Department of Error. The Lancet, 392(10150), 819-820.

Wagialla, N. A., \& Elnimeiri, M. K. M. (2016). Management of Hypertension by Primary Health Care Providers in Khartoum, Sudan. Public Health - Open Journal, 1(3), 66-70. https://doi.org/10.17140/phoj-1-113

Watine, J., Oosterhuis, W. P., Barth, J. H., Twomey, P. J., Misra, S., Aakre, K. M., \& Langlois, M. R. (2015). Why are clinical practice guidelines not followed? Clinical Chemistry and Laboratory Medicine (CCLM), 54(7), 1133-1139.

Zheng, G., Feng, L., \& Lewis, C. M. (2019). A data review of airway management in patients with oral cavity or oropharyngeal cancer : a single-institution experience. 1-7. 